\title{
Viability of lymphocyte culture, at different times after blood collection, for karyotype analysis
}

\author{
Viabilidade da cultura temporária de linfócitos, em diferentes \\ tempos após coleta do sangue, para análise de cariótipo
}

Ligia Maria Crubelati Bullaㅎ Eliane Papa Ambrosio²; Ana Beatriz Tozzo Martins³; Valter Augusto DellaRosa ${ }^{4}$

\begin{abstract}
Introduction: Cytogenetics is the area of genetics that studies chromosomes, including numerical changes, and their relationship to structural imbalances. Among the classical cytogenetics tests, the GTG banding karyotype is the most widely used. The period of culture establishment is a critical step, which can affect the pre-analytical phase of the test. Objective: To evaluate, at different establishment times, culture viability and banding resolution. Material and methods: Collection of $10 \mathrm{ml}$ blood from 10 subjects was carried out for culture analysis. For viability analysis, mitotic index (MI) and banding resolution were assessed. Results: The comparative analysis of MI showed significant difference between times. In the assessment of banding resolution, the mean value of the bands was higher at times zero and 24 hour. Discussion: The MI reflects inhibition of cell cycle progression and/or loss of ability to proliferate. When the pair analysis was performed, a difference between zero and 48 hours was observed. The average number of bands analyzed at times zero and 24 hours did not indicate difference in the quantity and quality of the bands when cultures were grown immediately after blood collection or within 24 hours. At the $48^{\text {th }}$ hour after blood collection significant reduction of band resolution was observed. Conclusion: These data highlight the importance of the biological material quality, as viability is lower when the culture is grown after 24 hours, as well as the banding resolution.
\end{abstract}

Key words: cytogenetics; karyotype; GTG banding; mitotic index.

\section{INTRODUCTION}

With the dissemination of knowledge about human and medical genetics by doctors of different specialties, human cytogenetics have gained importance with the karyotype tests, necessary in areas like gynecology, endocrinology, pediatrics, oncology, among others.

Human cytogenetics is an area that developed with the study of human chromosomes and encompasses their structure, organization, morphology and physiology. Tjio and Levan ${ }^{(23)}$, using cells of fetal pulmonary tissue, published that the correct number of chromosomes in human cells is 46 , what was confirmed in the same year in an independent study carried out by Ford and Hamerton ${ }^{(6)}$. Nowell ${ }^{(18)}$ described that phytohemagglutinin, a protein found in the plant Phaseolus vulgaris (Fabaceae), has the capacity to agglutinate erythrocytes and stimulate the mitosis of peripheral venous blood lymphocytes, enabling the obtainment of metaphase chromosomes from that tissue. Moorhead et al. ${ }^{(16)}$ developed a simple technique for the obtainment and study of metaphase chromosomes, bringing enormous advances to human cytogenetics. Thus, after the discovery of the chromosome number in humans, new cytogenetic techniques were developed, enabling to investigate correlations between karyotype and phenotype, with information becoming useful to understand the natural occurrence of chromosomal rearrangements ${ }^{(22)}$.

First submission on 04/12/13; last submission on 05/12/13; accepted for publication on 19/02/14; published on 20/04/14

1. Master's student of Environmental Biotechnology at Universidade Estadual de Maringá (UEM); post-graduate degree in Biotechnology Applied to Agribusiness from UEM.

2. Doctorate in Biological Sciences (Genetics) from Universidade Estadual Paulista Júlio de Mesquita Filho; assistant professor at UEM.

3. Doctorate in Numerical Methods in Engineering from Universidade Federal do Paraná (UFPR); associate professor at UEM.

4. Doctorate in Sciences, Biology/Genetics from Universidade de São Paulo (USP); senior associate professor at UEM. 
Cell culture originated in the $20^{\text {th }}$ century with researchers Harrison, in 1907, and Carrel, in 1912, which developed techniques to study the behavior of animal cells outside the organism, in a controlled environment. These techniques are still important in laboratories all over the world. The first experiments consisted of tissue cultures in vials containing fluids. Due to that form of culture, "tissue culture" is the term currently used to name cell, tissue and organ cultures ${ }^{(1)}$.

Correlations of numerical and structural chromosomal alterations with syndromic disorders were discovered in the dawn of cytogenetics era with the works by Lejeune et $a l$. $^{(12)}$, describing trisomy 21 in Down syndrome; Ford et al. ${ }^{(7)}$, describing monosomy X, in Turner syndrome; and Jacobs and Strongs ${ }^{(10)}$, describing the simultaneous presence of chromosomes XXY in Klinefelter syndrome. With the advent of chromosome banding, Q-bands ${ }^{(3)}, G-$ bands $^{(21)}$, C-bands ${ }^{(2)}$, and nucleolar organizing region (NOR) $)^{(15)}$ techniques, devised in the early 1970s, it was possible to identify individual chromosomes and more subtle changes, like deletions, duplications inversions, and translocations.

Duly banded chromosomes with moderate resolution produce on average 400 bands when they are less condensed ${ }^{(9)}$. In classical cytogenetic exams, the GTG banding karyotype is the routinely used methodology, considered the golden standard for the identification of chromosomal alterations. It makes it possible to identify major congenital abnormalities or delay in the development of a child ${ }^{(4)}$, besides being a screening technique of relatively low $\operatorname{cost}^{\left({ }^{(14)}\right)}$. Neither national nor international guidelines have been issued for karyotype analysis; the used convention is the analysis of 21 cells for numeric alterations, with five being structurally analyzed with a minimum of 400 bands.

From 1986, with the application of molecular cytogenetics and the use of probes of fluorescence in situ hybridization (FISH), it became possible to detect minor alterations, from $50 \mathrm{~Kb}$ to $100 \mathrm{~Kb}^{(13,14)}$. This was complementary to the classic karyotype analysis, when there was suspicion of chromosomal alterations that could not be visualized with the classical cytogenetics, or even for the investigation of extra marker chromosomes.

The karyotype test is carried out by a limited number of public and private laboratories in Brazil, since it demands knowledge about band patterns, experience, time and adequate conditions. Such laboratories are generally found in large centers and Regions South and Southeast ${ }^{(8)}$, what forces physicians, clinics and affiliated laboratories to draw blood and send it to these centers. Due to transport, cultures for obtainment of metaphase are set up more than 24 hours after blood collection, causing a possible reduction in exam quality or even its inviability, according to the elapsed time.

This work was aimed at assessing cellular viability and quality of metaphase at different times following collection: zero, 24, and 48 hours. The study simulated transport time up to the moment of culture growth, aiming at reducing interference in pre-analytical phase and delineating a margin of safety to ensure quality exams.

\section{MATERIAL AND METHODS}

\section{Sample characteristics}

Peripheral venous blood samples were drawn from five men and five women, all volunteers, with mean age of 32.3 , ranging from 19 to 60 years.

This study was approved by the Permanent Research Ethics Committee of the institution, and authors declare there is no conflict of interest.

\section{Peripheral blood lymphocyte culture}

Peripheral venous blood lymphocyte cultures were grown according to the technique of Moorhead $e t$ al.$^{(16)}$, with modifications, at different times after sampling. Three cultures were grown from each subject: the first, just after collection ( 0 hour); the second, 24 hours after collection; the third, 48 hours after collection. During the interval between initiation of a culture and another, the sample was stored at $4^{\circ} \mathrm{C}$.

Cultures were stimulated by fetal calf serum (15\%) (Cultilab), phytohemagglutinin (2\%) (Gibco), L-glutamine $200 \mathrm{nM}$ (1\%) (Gibco) and Roswell Park Memorial Institute medium (RPMI) without folic acid (Cultilab) for 72 hours at $37^{\circ} \mathrm{C}$, and interrupted by the addition of $100 \mu$ colchicine solution $0.016 \mathrm{mg} \mathrm{ml}^{-1}\left(\right.$ Sigma $\left.^{\circledR}\right) 40$ minutes before the $72^{\text {nd }}$ hour. Next, cells were centrifuged at 1,000 rpm for five minutes, submitted to a hypotonic solution of $\mathrm{KCl}(0.0075 \mathrm{M})$, and fixed twice with fixative solution (3 methanol: 1 acetic acid). After material was dropped on slides, these were stored at $20^{\circ} \mathrm{C}$ until being used.

\section{GTG banding}

For GTG banding, Seabright's modified technique was used $^{(21)}$. Slides were hydrolyzed in double concentration saline 
citrate $(2 \times \mathrm{SSC})$ for 10 minutes at $60^{\circ} \mathrm{C}$, rinsed in distilled water and dried at room temperature. Next, they were soaked in Sorensen's buffer containing trypsin $\left(3,9 \mu \mathrm{g} \mathrm{m}{ }^{-1}\right)$ for six seconds at $37^{\circ} \mathrm{C}$, rinsed and stained with $2 \%$ Giemsa solution for five minutes.

\section{Mitotic index analysis}

The mitotic index (MI) aims at identifying cell proliferation by metaphase counting. Metaphase is the most visible phase of cellular division, due to the degree of chromosome condensation ${ }^{(17)}$. MI analysis was determined under a light microscope, with final magnification of 400×. An amount of 1,000 cells per culture was observed, in total 3,000 cells for each subject, taking into consideration the three times of culture establishment in the study. The value is calculated as the percentage of cells under division, according to the formula 1: MI\% $=$ no. of metaphases $/ t$, in which $t$ represents the total number of counted cells.

\section{Chromosomal resolution analysis}

Band analysis was undertaken by image capturing using the system BandView, Spectral Imagining ${ }^{\circledR}$, joined to the light microscope that identifies the number of bands by metaphase, where they were captured with a magnification of $1,000 \times$. For each individual, metaphases for the three different times were captured and analyzed.

\section{Statistical analysis}

Statistical data obtained from MI were analyzed using Friedman test, which is a non-parametric test adequate to analyze results of an experimental delineation in casualized blocks, with samples paired according to formula 2 . There are the following hypotheses:

$\mathrm{H}_{0}$ : The number of metaphases found in the cells is the same for times zero, 24 and 48 hours.

$\mathrm{H}_{1}$ : The number of found metaphases is different for the analyzed times.

The delineation was performed in casualized blocks $(b=10)$, with three treatments, $\mathrm{k}=3$, using formula 2 , where $\mathrm{R}_{i}$ is the sum of orders attributed to elements $\left(R_{1}=28, R_{2}=18\right.$ and $\left.R_{3}=14\right)$. So, $\mathrm{X}^{2}=10.4$ and $p$ - value $=0.006$, at a $5 \%$ significance level. The hypothesis that the number of metaphases in each culture is the same for times zero, 24 and 48 hours was rejected, that is, at least one of the groups is different from the others, and to identify them it was necessary to carry out multiple comparisons, which consisted in testing the significance of the pairs of difference between times of initiation $i$ and $j(i \cdot j=1,2,3 ; i \neq j)$, by using the following inequality (formula 3), in which:

i) $\mathrm{R} i$ and $\mathrm{R} j$ are the sum of orders by column;

ii) $|\mathrm{R} i-\mathrm{R} j|$ is the observed difference;

iii) $Z$ is the critical difference observed at $\alpha=5 \%$ significance level.

\section{RESULTS}

The obtained count, with the numbers of metaphases, nuclei, and MI (in percentage) of the 10 subjects, from the short-term lymphocyte cultures, at times zero, 24 , and 48 hours, are summarized in the Table. Figure 1 exhibits a comparative graph with the numbers of metaphases of short-term peripheral blood lymphocyte cultures, of the 10 subjects, at times zero, 24, and 48 hours. The number of metaphases captured in cultures, at the different times, of subjects 3, 7, 9, and 10 showed gradual reduction. Regarding subjects 4 and 5 , there was increase in the number of metaphases in 24 hours, in relation to hour zero. The other subjects, 1, 2, 6, and 8 , showed increase in the number of metaphases in cultures set up at 48 hours, when compared to the values of 24 hours. However, a smaller number was observed at the zero hour.

For the employment of Friedman test, the obtained data were grouped according to the number of metaphases at different times (zero, 24 and 48 hours) to experimentally delineate the casualized blocks with paired samples to check hypotheses $\mathrm{H}_{0}$ and $\mathrm{H}_{1}$. In $\mathrm{H}_{0}$, the number of found metaphases is the same for times zero, 24 and 48 hours. In $\mathrm{H}_{1}$ the number of found metaphases is different for the analyzed times.

After the application of difference it was possible to observe that comparing times zero and 24 hours; 24 and 48 hours, the calculated value was lower than 10.4, and with difference between times zero and 48 hours, the value was higher than 10.4. Thus, through the test of multiple comparisons at 5\% significance level, sample evidence suggests that there is difference in the number of metaphases obtained between times zero and 48 hours.

Using the BandView image acquisition system, the number of bands was counted for each metaphase, by subject, calculating averages, at the different times (zero, 24 and 48 hours). The average number of visualized bands at times zero, 24 and 48 hours were, respectively, 408.7, 404.3, and 349.3, as shown in Figure 2.

In the samples from which metaphases were not obtained, or in the low MI samples, metaphases were not captured, 
TABLE - Number of metaphases, nuclei, and mitotic index, by subject, obtained from lymphocytes cultured at times zero, 24 hours and 48 hours

\begin{tabular}{|c|c|c|c|c|c|c|}
\hline \multirow[t]{2}{*}{ Subjects } & \multirow{2}{*}{$\begin{array}{c}\text { Times } \\
0 \mathrm{~h}\end{array}$} & \multirow[t]{2}{*}{ Sex } & \multirow{2}{*}{$\begin{array}{c}\text { Age } \\
\text { (years) }\end{array}$} & \multicolumn{2}{|c|}{ Metaphases } & \multirow{2}{*}{$\begin{array}{c}\begin{array}{c}\text { Nuclei } \\
\text { MI (\%) }\end{array} \\
3.1\end{array}$} \\
\hline & & & & 31 & 969 & \\
\hline \multirow[t]{3}{*}{1} & $24 \mathrm{~h}$ & Male & 60 & 16 & 984 & 1.6 \\
\hline & $48 \mathrm{~h}$ & & & 30 & 970 & 3 \\
\hline & $0 \mathrm{~h}$ & & & 28 & 972 & 2.8 \\
\hline \multirow[t]{3}{*}{2} & $24 \mathrm{~h}$ & Female & 55 & 4 & 996 & 0.4 \\
\hline & $48 \mathrm{~h}$ & & & 18 & 982 & 1.8 \\
\hline & $0 \mathrm{~h}$ & & & 32 & 968 & 3.2 \\
\hline \multirow[t]{3}{*}{3} & $24 \mathrm{~h}$ & Male & 25 & 29 & 971 & 2.9 \\
\hline & $48 \mathrm{~h}$ & & & 5 & 995 & 0.5 \\
\hline & $0 \mathrm{~h}$ & & & 26 & 974 & 2.6 \\
\hline \multirow[t]{3}{*}{4} & $24 \mathrm{~h}$ & Female & 20 & 30 & 970 & 3 \\
\hline & $48 \mathrm{~h}$ & & & 2 & 998 & 0.2 \\
\hline & $0 \mathrm{~h}$ & & & 29 & 971 & 2.9 \\
\hline \multirow[t]{3}{*}{5} & $24 \mathrm{~h}$ & Male & 28 & 30 & 970 & 3 \\
\hline & $48 \mathrm{~h}$ & & & 0 & 625 & 0 \\
\hline & $0 \mathrm{~h}$ & & & 16 & 984 & 1.6 \\
\hline \multirow[t]{3}{*}{6} & $24 \mathrm{~h}$ & Female & 24 & 3 & 997 & 0.3 \\
\hline & $48 \mathrm{~h}$ & & & 7 & 993 & 0.7 \\
\hline & $0 \mathrm{~h}$ & & & 18 & 982 & 1.8 \\
\hline \multirow[t]{3}{*}{7} & $24 \mathrm{~h}$ & Male & 26 & 15 & 985 & 1.5 \\
\hline & $48 \mathrm{~h}$ & & & 8 & 992 & 0.8 \\
\hline & $0 \mathrm{~h}$ & & & 21 & 979 & 2.1 \\
\hline \multirow[t]{3}{*}{8} & $24 \mathrm{~h}$ & Female & 30 & 13 & 987 & 1.3 \\
\hline & $48 \mathrm{~h}$ & & & 14 & 986 & 1.4 \\
\hline & $0 \mathrm{~h}$ & & & 25 & 975 & 2.5 \\
\hline \multirow[t]{3}{*}{9} & $24 \mathrm{~h}$ & Male & 36 & 23 & 977 & 2.3 \\
\hline & $48 \mathrm{~h}$ & & & 2 & 998 & 0.2 \\
\hline & $0 \mathrm{~h}$ & & & 26 & 974 & 2.6 \\
\hline \multirow[t]{2}{*}{10} & $24 \mathrm{~h}$ & Female & 19 & 19 & 981 & 1.9 \\
\hline & $48 \mathrm{~h}$ & & & 13 & 987 & 1.3 \\
\hline
\end{tabular}

because they did not present a convenient morphological model and did not fit the analyzed patterns. Figure $\mathbf{3}$ represents the average karyotype pattern of analysis at the three observed times.

\section{DISCUSSION}

To our knowledge and based on the literature review, there is no work correlating the different times of establishment of human lymphocyte culture and their viability for karyotype analysis.

Human lymphocytes, of peripheral venous blood, are in the cellular cycle, at the resting phase (G0), and after being placed in cultures, in the presence of phytohemagglutinin, are stimulated to divide. After 48 hours in culture, they are, in their majority, in their first mitotic division ${ }^{(20)}$. So, for the obtainment of a larger number of cells in metaphase, one should wait for another 24-hour division cycle, and cultures are interrupted for analysis after 72 hours.

MI represents the proportion of cells in metaphase in a population of studied cells, indicating their degree of proliferation ${ }^{(19)}$. The MI is widely used as an indicator of cell proliferation. The decrease in MI values reflects the inhibition of progression of the cell cycle and/or loss of capacity to proliferate ${ }^{(11)}$. Mitotic inhibition may be due to cell death or delayed cell cycle ${ }^{(5)}$, what explains the reduced number of metaphases in most cases when values obtained in 48-hour cultures are observed.

When comparing MI in pairs (zero with 24 hours; zero with 48 hours; 24 with 48 hours) among the analyzed times, a significant

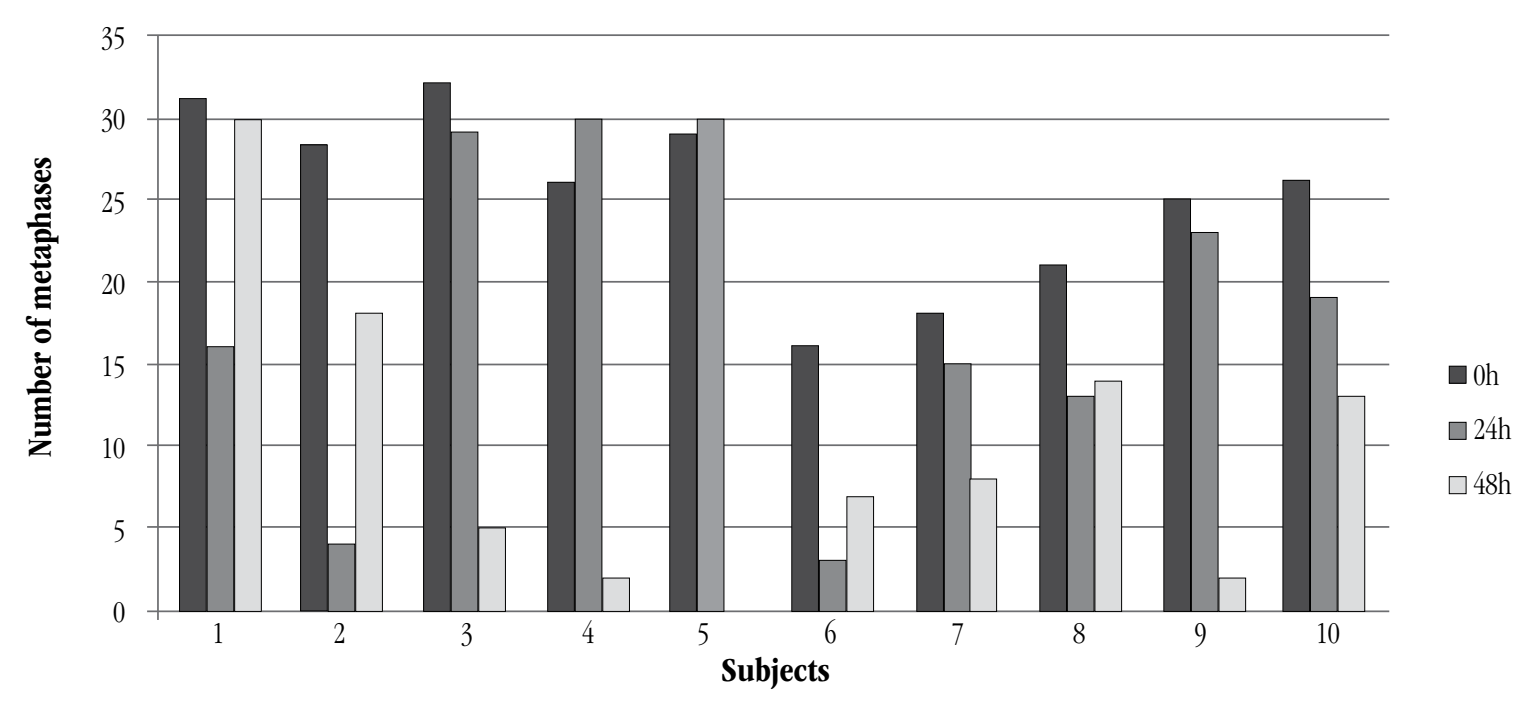

FIGURE 1 -Numbers of metaphases in cultures, by subject, at times zero, 24, and 48 hours 


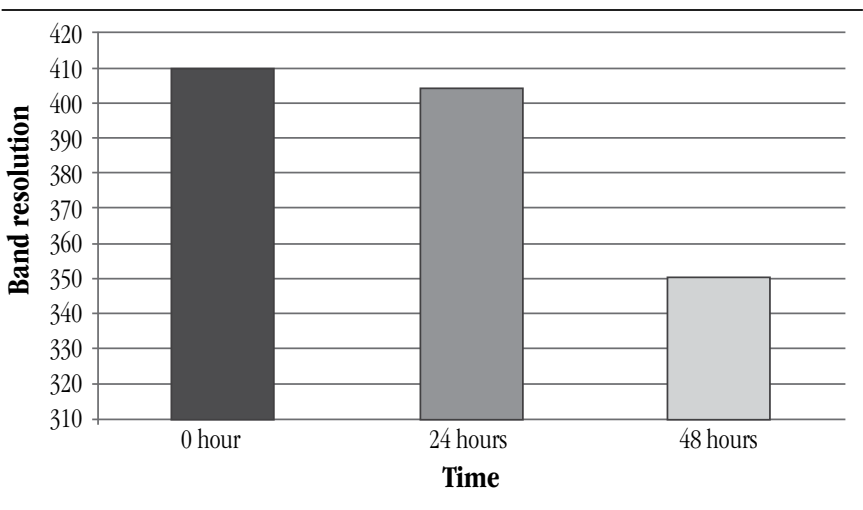

FIGURE 2 -Average number of bands, per subject, at the different culture times

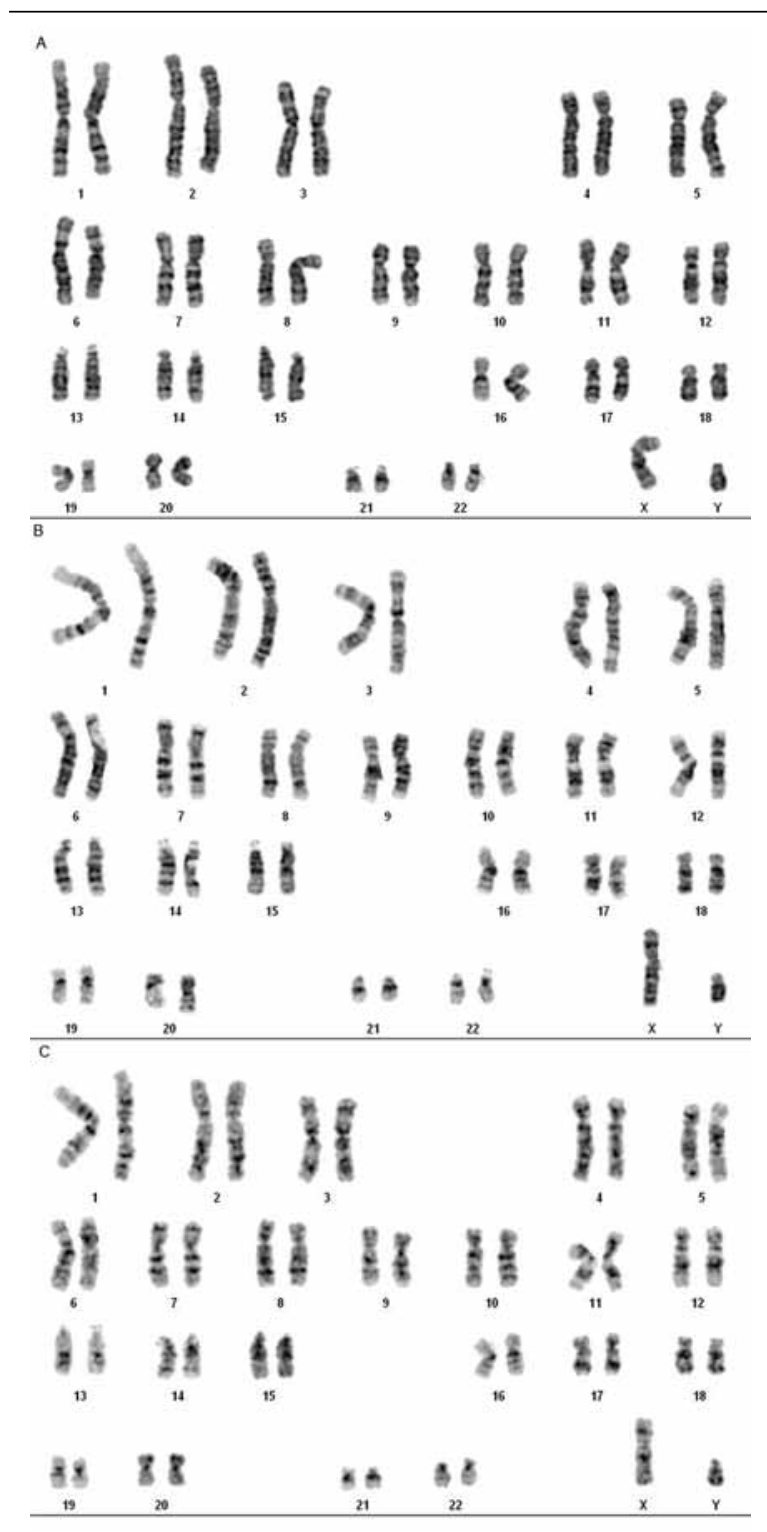

FIGURE 3 -Metaphases obtained from lymphocytes cultured at different times, GTG banding

A) $0 \mathrm{~b}$ with 500 bands; B) $24 \mathrm{~b}$ with 450 bands; C) $48 \mathrm{~b}$ with 350 bands.

\section{Formula 2}

$$
\mathrm{x}^{2}=\frac{12}{\mathrm{bk}(\mathrm{k}+1)}\left(\sum_{\mathrm{i}=\mid}^{\mathrm{k}} R_{\mathrm{i}}^{2}\right)-3 b(\mathrm{k}+1)
$$

Formula 3
$|R \mathrm{i}-R \mathrm{j}| \geq Z\left(\frac{\mathrm{a}}{k(k-1)}\right) \sqrt{\frac{b \cdot k(k+1)}{6}}$

FIGURE 4 - Formulas cited in "Material and methods"

difference was observed between times zero and 48 hours, because there was a considerable reduction in the number of metaphases obtained in cultures from zero hour to culture after 48 hours. Thus, one may consider the time of up to 24 hours in the preanalytical phase for karyotype tests does not endanger the quality of results.

The average number of GTG bands analyzed at times zero and 24 hours were, respectively, 408.7 and 404.3 , showing that there was no difference as to quality of GTG bands when cultures were set up just after blood collecti on or within 24 hours. On the 48-hour time after collection, there was significant reduction of the average number of bands GTG (349.3), what is below the average of 400 bands used by convention for routine laboratory analysis ${ }^{(9)}$. Resolution is fundamental for identification of chromosomal alterations, in which higher resolution may detect smaller alterations. The chromosomal band contains, on average, between five and 10 mega bases of DNA, including hundreds of genes. In the GTG banding method, Giemsa-positive (dark) bands have in their composition a larger number of A-T nucleotides, containing few genes, and replicate late. On the other hand, Giemsa-negative (light) bands are rich in $\mathrm{C}-\mathrm{G}$ nucleotides, with a large quantity of genes, and their replication begins earlier ${ }^{(9)}$.

\section{CONCLUSION}

The pre-analytical phase and the culture time of venous peripheral blood after collection are fundamental for the quality of the karyotype test. It was observed that there is a safety margin of up to 24 hours after blood collection; after this time, cellular viability decreases significantly. Besides, resolution of the bands obtained within this period remains in approximately 400 bands, ensuring a good quality exam with highly reliable results. 


\section{RESUMO}

Introdução: Citogenética é a área da genética que estuda os cromossomos, incluindo alterações numéricas, estruturais e sua relação com distúrbios. Nos exames de citogenética clássica, o cariótipo com bandamento GTG é a metodologia mais utilizada, sendo o período de implantação da cultura uma fase crítica, que pode comprometer a fase pré-analítica do exame. Objetivo: Avaliar, em diferentes tempos de implantação, a viabilidade das culturas e o número de bandas. Material e métodos: Foram colbidos $10 \mathrm{ml}$ de sangue de 10 sujeitos para realização das culturas. Para análise da viabilidade, foram utilizados o índice mitótico (IM) e a análise de resolução por bandamento. Resultados: A comparação dos valores do IM demonstrou desigualdade entre os diferentes tempos analisados. Na análise de resolução, o valor médio das bandas foi maior nos tempos zero e 24 horas. Discussão: 0 IM reflete a inibição da progressão do ciclo celular e/ou a perda da capacidade de proliferação. Quando o IM foi comparado dois a dois, verificou-se a diferença entre os tempos zero e 48 horas. O número médio de bandas analisadas nos tempos de zero e 24 boras mostrou que não houve diferença na quantidade e na qualidade das bandas quando as culturas foram implantadas logo após a coleta do sangue ou em até 24 boras. No tempo de 48 horas, bouve significativa redução da resolução. Conclusão: Os dados obtidos reforçam a importância da qualidade do material biológico, visto que a viabilidade decai quando a implantação da cultura é realizada após 24 horas, assim como a resolução das bandas.

Unitermos: citogenética; cariótipo; bandamento GTG; índice mitótico.

\section{REFERENCES}

1. ALVES, E. A.; GUIMARÃES, A. C. R. Cultivo celular. In: MOLINARO, E. M.; CAPUTO, L. F. G.; AMENDOERIA, M. R. R. A. (Eds.) Conceitos e métodos para formação de profissionais em laboratório. v. 2. Rio de Janeiro: EPSJ, IOC, 2010. p. 215-53.

2. ARRIGHI, F. E.; HSU, T. C. Localization of heterochromatin in human chromosomes. Cytogenetics, v. 10, n. 2, p. 81-6, 1971.

3. CASPERSSON, T. et al. Identification of human chromosomes by DNAbinding fluorescent agents. Chromosoma, v. 30, n. 2, p. 215-27, 1970.

4. DAVE, B. J.; SANGER, W. G. Role of cytogenetics and molecular cytogenetics in the diagnosis of genetic imbalances. Semin Pediatr Neurol, v. 14, n. 1, p. 2-6, 2007.

5. ERO LU, H. E. et al. In vitro cytotoxic effects of methanol extracts of six helichrysum taxa used in traditional medicine. Pak J Bot, v. 42, n. 5 , p. 3229-37, 2010.

6. FORD, C. E.; HAMERTON, J. L. A colchicine, hypotonic citrate, squash sequence for mammalian chromosome. Stain Technol, v. 31, n. 6, p. 247-51, 1956.

7. FORD, C. E. et al. A sex-chromosome anomaly in a case of gonadal dysgenesis (Turner's syndrome). Lancet, v. 1, n. 7075, p. 711-3, 1959.

8. HOROVITZ, D. D. G. et al. Genetic services and testing in Brazil. J Community Genet, v. 4, n. 3, p. 355-75, 2013.

9. ISCN (2009): An international system for buman cytogenetic nomenclature. SHAFFER, L. G.; SLOVAK, M. L.; CAMPBELL, L. J. (eds). S Kager, Basel, 2009.

10. JACOBS, P. A.; STRONG, J. A. A case of human intersexuality having a possible XXY sex-determininig mechanism. Nat Rev, v. 183, n. 31, p. 302-3, 1959.
11. KASURKA, C. B; SEKERO LU, Z. A.; SEKERO LU, Z. Evaluation of the genotoxicity and cytotoxicity of fexofenadine in cultured human peripheral blood lymphocytes. Toxicol in Vitro, v. 25, n. 7, p. 1480-4, 2011.

12. LEJEUNE, J.; GAUTIER, M.; TURPIN, R. Etude dês chromosomes somatiques de neuf enfants mongoliens. C R Acad Sci, v. 248, n. 11, p. 1721-2, 1959 .

13. LI, M. M.; ANDERSON, H. C. Clinical application of microarray-based molecular cytogenetics: an emerging new era of genomic medicine. JPediatr, v. 155, n. 3, p. 311-7, 2009

14. LIEHR, T.; POLLESTOR, F. Molecular cytogenetics: the standard FISH and PRINS procedure. In: LIEHR, T. (Eds). Fluorescence in situ bybridizations (FISH) - Application Guide. Berlin: Springer, 2009. p. 23-34.

15. MATSUI, S.; SASAKI, M. Differential staining of nucleolus organizers in mammalian chromosomes. Nat Rev, v. 246, p. 148-50, 1973.

16. MOORHEAD, P. S. et al. Chromosome preparations of leukocytes cultured from human peripheral blood. Exp Cell Res, v. 20, n. 3, p. 613-6, 1960.

17. MOREIRA, F. C. Reconhecimento e classificação de padrões de imagens de núcleos de linfócitos do sangue periférico bumano com a utilização de redes neurais artificiais. Florianópolis, 2002. Dissertação (mestrado) - Universidade Federal de Santa Catarina.

18. NOWELL, P. C. Phytohemagglutinin: an initiator of mitosis in culture of normal human leukocytes. Canc Res, v. 20, p. 462-6, 1960.

19. OECD GUIDELINE FOR THE TESTING OF CHEMICALS. In vitro mammalian chromosome aberration test. Adopted, 2010.

20. RABELLO-GAY, M. N. Teste com linfócitos de sangue periférico. In: RABELLO-GAY. M. N.; RODRIGUES, M. A. MONTELEONE-NETO, R. 
Mutagênese, teratogênese e carcinogênese: métodos e critérios de avaliação. Riberão Preto, SBG, 1991. p. 97-103.

21. SEABRIGHT, M. A rapid banding technique for human chromosomes. Lancet, v. 298, n. 7731, p. 971-2, 1971.
22. TRASK, M. J. Human cytogenetics: 46 chromosomes, 46 years and counting. Nat Rev Genet, v. 3, n. 10, p. 769-78, 2002.

23. TJIO, J. H.; LEVAN, A. The chromosome number in man. Hereditas, v. 42 , p. 1-6, 1956

\section{MAILING ADDRESS}

Valter Augusto Della Rosa

IDepartamento de Biotecnologia, Genética e Biologia Celular; Universidade Estadual de Maringá; Av. Colombo, 5.790; Jardim Universitário; CEP: 87020-900; Maringá-PR, Brazil; Phone: +55 (44) 3011-4894; e-mail: epambrosio2@uem.br. 